\section{Pan-African Congress on Prehistory}

THe Government of Kenya has agreed that a Pan. African Congress on Prehistory (Archæology) shall be convened in Nairobi, Kenya Colony, during January 11-February 1, 1947. The Congress will be concerned with the prehistory of the African continent, and the discussions will also include relevant subjects, such as those aspects of palæontology which intimately concern prehistory, climatic changes and quaternary geology in relation to prehistory. It is proposed that the Congress should be divided into two parts. The first three and a half days will be devoted to discussions upon problems of a general nature, including the following : terminology for the various pluvial periods and post-pluvial phases of the Pleistocene; terminology for the stone-age cultures in Africa; definitions of the words 'Pliocene' and 'Pleistocene' with the view of reaching an agreed definition throughout the African continent; cooperation in respect of research programmes in pre. history and allied subjects in the various African territories; protection of prehistoric sites and of other sites of connected interest; control of excavations; future of research into prehistory and allied subjects in African territories. The second part of the Congress will be devoted to the reading of papers and to discussions upon discoveries made in the field of prehistory since 1939 , and more particularly to such discoveries as have had little publicity outside the territories in which they were made, owing to wartime conditions. Excursions to sites in East Africa are planned to take place both during the days immediately preceding the Congress and also during the week following the Congress. The former is designed to give delegates an opportunity of seeing the principal type sections upon which the pluvial and post-pluvial climatic changes for Kenya were originally based, and also to see some of the more important prehistoric sites in the Rift Valley. During the Congress, there will be an excursion to the Olorgesailie prehistoric site, which is being developed as a 'museum on the spot' to illustrate the evolution of the Acheulean culture. It is hoped to obtain special air-travel facilities for delegates to the Congress. All correspondence relating to the Congress should be addressed to Dr. L. S. B. Leakey, Organising Secretary, P.O. Box 658, Nairobi, Kenya.

\section{Science and Art of Medicine}

THe appointment of Sir Lionel Whitby to the regius chair of physic at Cambridge marks, as Sir Lionel himself says in his inaugural lecture ("The Science and Art of Medicine." Cambridge University Press, 1946. 1s. 6d. net), a departure from the traditions of this ancient office, which was founded in 1540. It is, Sir Lionel says, the first time that the chair has been held by a man who is primarily interested in the scientific rather than the clinical aspects of medicine. This may well be "an instinctive recognition of the importance of the scientific aspects of medicine, not forgetting that science is not all factual and itself contains much art". Medicine, too, he says later on, is both a science and an art. It will, however, never be an exact science, because every person who is ill must be approached differently. "This, the frequently ridiculed bedside manner ... is an art which is inborn and not acquired." The science of medicine is nevertheless necessary; and one of the attractions of the profession is the personal and individual character of its practice, which constitutes one of the strongest objections to its nationalization and standardization. To-day, we "do not tend" to produce physicians as skilled and shrewd in diagnosis as those earlier workers who had to rely entirely on their personal observation; and the modern student, with so many scientific checks at his command, will do well to imitate his forbears more closely by "carefully orientating his cases before demanding wholesale laboratory work".

Before the beginning of this century, the medical practitioner was skilful in alleviating symptoms, but knew little or nothing about the causes of disease. From 1890 onwards the treatment of disease in relation to its cause rather than the treatment of its symptoms began to be developed. The beginning was made in immunology with diphtheria antitoxin. Sir Lionel then reviews briefly the immunological work of Ehrlich and his later search for specific remedies which would kill infecting organisms without harming the tissues of the body in which they cause disease. Examples follow of the use of art and imagination in modern chemotherapeutic discovery, with a timely warning against the unbridled use of the sulphonamides. There are no facts in this lecture which will not be familiar to those who have followed recent chemotherapeutic work; but the use which the author makes of the facts which he gives is both charming and remarkable.

\section{Biologia Generalis}

Biologia Generalis was founded in 1925 and published in Vienna and New York. Its aim was to provide a place for the publication of papers on general biology in the wide sense, rather than those that fall strictly within the field of either botany or zoology. It included border-line topies like aspects of physical or bio-chemistry that have application to biology or medicine, viruses, genetics, general cytology, the history and philosophy of biology and various other subjects. Messrs. Springer, of Vienna, are now resuming publication of the journal under the editorship of Prof. Ludwig von Bertalanffy. The editor points out that the War very profoundly affected the exchange of scientific knowledge and ideas, and that the biologists of Central Europe in particular have been practically isolated while it lasted. Biologia Generalis is the first biological journal to be issued in Austria since the period of reconstruction, and the editor appeals to his colleagues of the outside world for their help and support in re-establishing the international co-operation in biology that existed previously. Articles will be accepted for publication in English, French, German and Italian; the editor's address is Wien $111 / 40$ Weissgärberlände 52.

\section{British Glaciological Society}

IN 1936 the Association for the Study of Snow and Ice was formed, the primary object of which was "to encourage research on, and stimulate interest in, the practical and scientific problems of snow and ice". Since then, the Association has broadened its activities. For example, it is the responsible body for nominating members of the British group of the International Commission of Snow and Glaciers, which is one of the commissions of the International Association of Hydrology in the International Union of Geodesy and Geophysics ; and it is resuming its annual survey of snowfall in the British Isles. A change in name has now been decided upon, and the Association will be known in future as the British 